\title{
The role of phosphorus dynamics in tropical forests - a modeling study using CLM-CNP
}

\author{
X. Yang, P. E. Thornton, D. M. Ricciuto, and W. M. Post \\ Oak Ridge National Lab, Oak Ridge, TN 37831, USA \\ Correspondence to: X. Yang (yangx2@ornl.gov) \\ Received: 26 July 2013 - Published in Biogeosciences Discuss.: 28 August 2013 \\ Revised: 10 February 2014 - Accepted: 11 February 2014 - Published: 28 March 2014
}

\begin{abstract}
Tropical forests play a significant role in the global carbon cycle and global climate. However, tropical carbon cycling and the feedbacks from tropical ecosystems to the climate system remain critical uncertainties in the current generation of carbon-climate models. One of the major uncertainties comes from the lack of representation of phosphorus $(\mathrm{P})$, currently believed to be the most limiting nutrient in tropical regions. Here we introduce $\mathrm{P}$ dynamics and $\mathrm{C}-\mathrm{N}-$ $\mathrm{P}$ interactions into the CLM4-CN (Community Land Model version 4 with prognostic Carbon and Nitrogen) model and investigate the role of $\mathrm{P}$ cycling in controlling the productivity of tropical ecosystems. The newly developed CLM-CNP model includes all major biological and geochemical processes controlling $\mathrm{P}$ availability in soils and the interactions between $\mathrm{C}, \mathrm{N}$, and $\mathrm{P}$ cycles. Model simulations at sites along a Hawaiian soil chronosequence indicate that the introduction of P limitation greatly improved the model performance at the P-limited site. The model is also able to capture the shift in nutrient limitation along this chronosequence (from $\mathrm{N}$ limited to $\mathrm{P}$ limited), as shown in the comparison of modelsimulated plant responses to fertilization with the observed data. Model simulations at Amazonian forest sites show that CLM-CNP is capable of capturing the overall trend in NPP (net primary production) along the $\mathrm{P}$ availability gradient. This comparison also suggests a significant interaction between nutrient limitation and land use history. Model experiments under elevated atmospheric $\mathrm{CO}_{2}\left(\left[\mathrm{CO}_{2}\right]\right)$ conditions suggest that tropical forest responses to increasing $\left[\mathrm{CO}_{2}\right]$ will interact strongly with changes in the $\mathrm{P}$ cycle. We highlight the importance of two feedback pathways (biochemical mineralization and desorption of secondary mineral $\mathrm{P}$ ) that can significantly affect $\mathrm{P}$ availability and determine the extent of $\mathrm{P}$ limitation in tropical forests under elevated $\left[\mathrm{CO}_{2}\right]$.
\end{abstract}

Field experiments with elevated $\mathrm{CO}_{2}$ are therefore needed to help quantify these important feedbacks. $\mathrm{CO}_{2}$ doubling model experiments show that tropical forest response to elevated $\left[\mathrm{CO}_{2}\right]$ can only be predicted if the interactions between $\mathrm{C}$ cycle and nutrient dynamics are well understood and represented in models. Predictive modeling of $\mathrm{C}$-nutrient interactions will have important implications for the prediction of future carbon uptake and storage in tropical ecosystems and global climate change.

\section{Introduction}

It is generally agreed that tropical forests play a significant role in the global carbon (C) cycle and global climate. Tropical forests account for at least one third of the global annual net primary production (NPP) in the terrestrial biosphere (Melillo et al., 1993), contain about $25 \%$ of the world's vegetation biomass and soil carbon (Jobbágy and Jackson, 2000), and exchange more water and carbon with the atmosphere than any other biome (Foley et al., 2005). The high rates of $\mathrm{CO}_{2}$ exchange between the tropical ecosystem and the atmosphere, along with the globally significant amount of carbon storage in tropical ecosystems, suggest that changes in tropical ecosystems in response to changing environmental conditions can affect the pace of atmospheric $\mathrm{CO}_{2}$ increase and climate change (Clark, 2007).

In spite of the likely significance of tropical ecosystems to the global carbon cycle, tropical carbon cycle processes and the feedbacks to the climate system remain critically uncertain in current generation carbon-climate models (Friedlingstein et al., 2006). Most of the uncertainties arose from differences in model sensitivities to drought stress, 
increased temperature, $\mathrm{CO}_{2}$ fertilization, disturbances, and nutrient availability (Piao et al., 2013; Zaehle and Dalmonech, 2011; Arneth et al., 2010). Another important problem for the current generation of nutrient-enabled models, such as CLM-CN (Thornton et al., 2009, 2007) and O-CN (Zaehle et al., 2010), is the lack of consideration of the $\mathrm{P}$ cycle and $\mathrm{P}$ limitation.

Phosphorus has been considered as the most limiting nutrient in tropical regions. From the pedogenic perspective, soils in lowland tropics have gone through hundreds of millions of years of development so there is minimal parent material $\mathrm{P}$ available to provide fresh input of $\mathrm{P}$ through weathering (Walker and Syers, 1976; Yang and Post, 2011). The intense weathering in tropical lowland forests also leads to the prevalence of $1: 1$ clays (e.g., kaolinite) and aluminum and iron oxides and hydroxides that effectively sorb P (Sanchez, 1976), which result in low $P$ availability in tropical soils and strong P limitation for tropical ecosystems. Observations of plant and soil properties - leaf, litter and soil organic matter - generally show increasing $\mathrm{C}: \mathrm{P}$ and $\mathrm{N}: \mathrm{P}$ ratios from high latitude to low latitude, another indication of $\mathrm{P}$ limitation (McGroddy et al., 2004a; Reich and Oleksyn, 2004; Cleveland and Liptzin, 2007; Yang and Post, 2011). Fertilization experiments also provide direct evidence for $\mathrm{P}$ limitation in tropical lowland forests (Elser et al., 2007; Wright et al., 2011).

The interactions of $\mathrm{C}, \mathrm{N}$, and $\mathrm{P}$ play important roles in regulating the availability of $\mathrm{N}$ and $\mathrm{P}$ and carbon uptake and storage in terrestrial ecosystems. There is evidence suggesting the importance of $\mathrm{P}$ and/or molybdenum (Mo) availability in regulating N fixation (Hungate et al., 2004; Reed et al., 2013; Barron et al., 2008). Field experiments demonstrated that additions of $\mathrm{P}$ can increase $\mathrm{N}$ fixation and $\mathrm{N}$ availability in terrestrial ecosystems (Edwards et al., 2006; Crews et al., 2000). Conversely, $\mathrm{N}$ availability can affect the availability of $\mathrm{P}$ by controlling the production of phosphatase, a group of N-rich enzymes that can release $\mathrm{P}$ from organic form independently of carbon oxidation and increase $\mathrm{P}$ availability (McGill and Cole, 1981; Wang et al., 2007; Houlton et al., 2008; Olander and Vitousek, 2000; Treseder and Vitousek, 2001). In a metaanalysis using 34 separate fertilization studies, Marklein and Houlton (2012) showed P cycling may be accelerated via enhanced biochemical mineralization rate when $\mathrm{N}$ availability increases.

Recent work has highlighted the importance of $\mathrm{P}$ in tropical forest productivity and function by analyzing field measurement data. Aragao et al. (2009) suggested that total NPP tends to increase with the availability of soil phosphorus, but does not respond clearly to soil nitrogen availability across ten Amazonian sites. Quesada et al. (2012) indicated that total soil $\mathrm{P}$ is the single most important factor directly affecting wood production rates in Amazon forests. Some progress has been made on the relationship between leaf $\mathrm{P}$ concentration and photosynthesis, emphasizing the role of leaf $\mathrm{P}$ concen- tration in determining photosynthetic capacity (Reich et al., 2009; Domingues et al., 2010; Mercado et al., 2011).

Despite the importance of the $\mathrm{P}$ cycle in regulating terrestrial carbon uptake, especially in tropical regions, very few carbon-climate models have considered $\mathrm{P}$ dynamics and $\mathrm{C}-$ N-P interactions with the exception of CASA (CarnegieAmes-Stanford Approach)-CNP and JSBACH-CNP (Wang et al., 2007, 2009; Goll et al., 2012). This omission is explained in part by the fact that the evaluation of the global carbon cycle models has been focused on temperate regions, where $\mathrm{N}$ instead of $\mathrm{P}$ is the most limiting nutrient and also by the complexity of the $\mathrm{P}$ cycle itself. In addition, the links between $\mathrm{P}$ cycle and $\mathrm{C}$ and $\mathrm{N}$ cycles are not all that self-evident. The $\mathrm{P}$ cycle is very different from the $\mathrm{N}$ cycle. Unlike nitrogen, there is no significant atmospheric component for the $\mathrm{P}$ cycle. The primary source of $\mathrm{P}$ for terrestrial ecosystems is through rock weathering, and the P cycle therefore operates on geological timescales. There are various forms of $P$ in soils, which have different degrees of availability for plant uptake and microbe utilization. The transformations between various $\mathrm{P}$ forms are much more complicated than those of $\mathrm{N}$, involving a series of biological and geochemical processes on timescales ranging from seconds to millions of years. The long timescales involved make the $\mathrm{P}$ cycle problem very much an initial value problem for models that operate typically on timescales of centuries or less, in which the P cycle does not equilibrate. Yang et al. (2013) provided global maps of various $\mathrm{P}$ pools that can be used for the initialization of these models. The physiology of $\mathrm{P}$ limitation and $\mathrm{N}$ limitation is also different. Nitrogen is a major constituent of photosynthesis enzymes (mainly Rubisco) and light capturing proteins of thylakoid (Evans, 1989). Phosphorus is required for various processes such as the production of ATP (adenosine triphosphate) from ADP (adenosine diphosphate) and the regeneration of RuBP (ribulose-1,5-bisphosphate; Geiger and Servaites, 1994; Campbell and Sage, 2006). Plant growth requires larger quantities of $\mathrm{N}$ than $\mathrm{P}$ so $\mathrm{C}: \mathrm{N}$ ratios are smaller than $\mathrm{C}: \mathrm{P}$ ratios in terrestrial ecosystems (McGroddy et al., 2004a).

Here we introduce a $\mathrm{P}$ component into the CLM4-CN (Community Land Model version 4 with prognostic Carbon and Nitrogen) model. We evaluate the performance of CLM-CNP by applying the model at sites along a chronosequence in Hawaii and at five additional tropical forest sites. We then investigate how $\mathrm{C}-\mathrm{P}$ interactions might affect forest responses to increasing atmospheric $\mathrm{CO}_{2}$ using the newly developed model. The objectives are twofold: (1) construct a modeling framework with $\mathrm{P}$ dynamics that will improve representation of $\mathrm{C}-$ nutrient interactions in tropical ecosystems, and (2) identify the important tropical processes involving $\mathrm{P}$ dynamics and $\mathrm{C}-\mathrm{P}$ interactions that significantly affect the $\mathrm{C}$-climate feedbacks but need better understanding and quantification. 


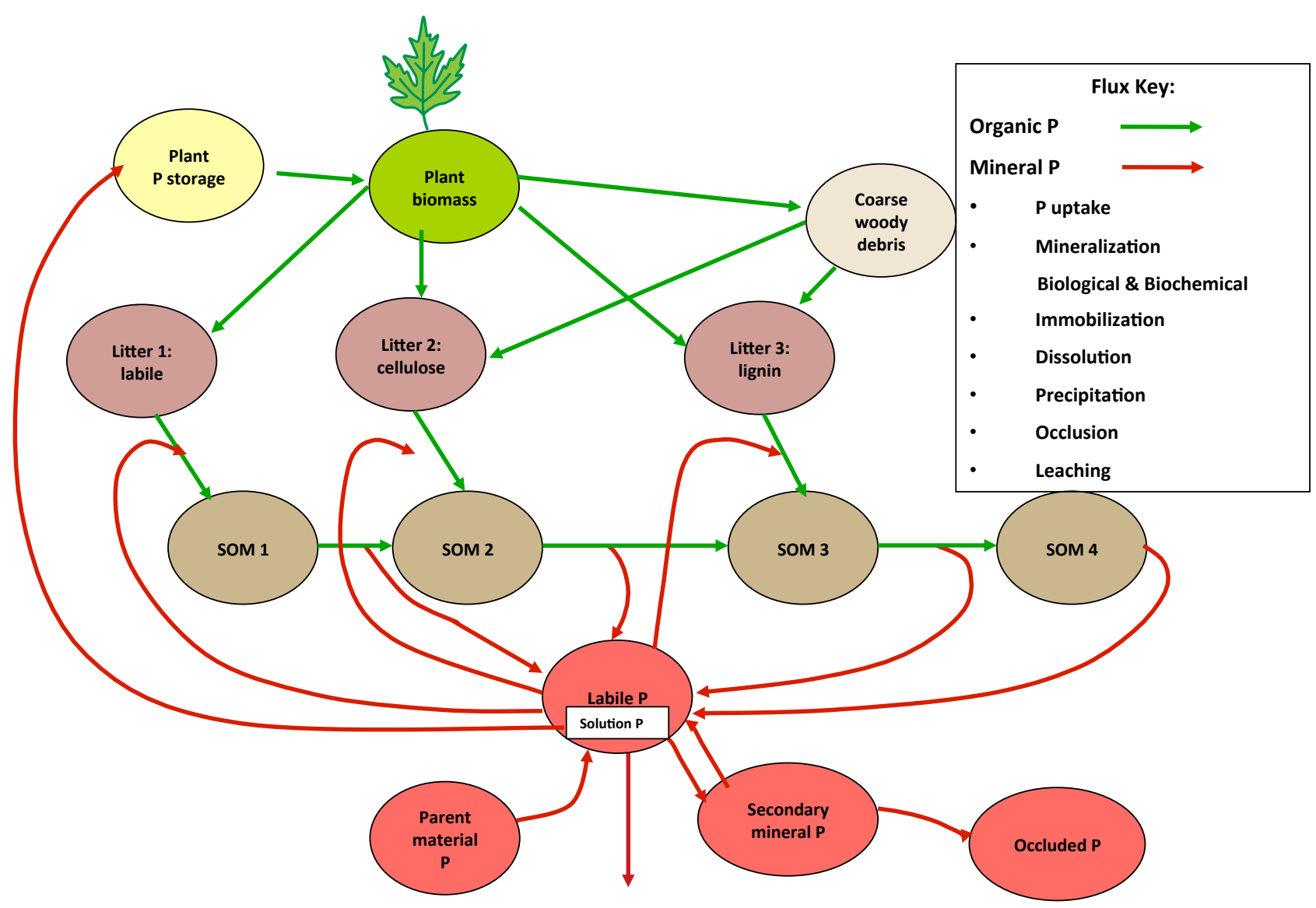

Fig. 1. Pools and fluxes of $\mathrm{P}$ components in CLM-CN (solution $\mathrm{P}$ is assumed to be in equilibrium with the labile $\mathrm{P}$ pool).

\section{Methods}

\subsection{Model description}

The CLM-CNP model is based on the land biogeochemistry model CLM-CN in the community land model (CLM4.0). CLM-CN is fully prognostic with respect to all carbon and nitrogen state variables in vegetation, litter, and soil organic matter and has been successfully applied on the global scale for the investigation of the role of $\mathrm{N}$ limitation in terrestrial uptake and its response to environmental changes (Thornton et al., 2007, 2009).

The P cycle in CLM-CNP is designed to build our capacity to better understand $\mathrm{P}$ dynamics and to address the role of $\mathrm{P}$ limitation in terrestrial ecosystems. As shown in the phosphorus submodel diagram (Fig. 1), we consider phosphorus in plant biomass (leaves, fine roots, live wood, dead wood, live coarse root, dead coarse root, and fine root), plant storage pool, coarse woody debris, three litter pools, four soil organic matter compartments, and five soil inorganic phosphorus pools including solution $\mathrm{P}$, labile $\mathrm{P}$, secondary mineral $\mathrm{P}$, parent material $\mathrm{P}$, and occluded $\mathrm{P}$. The principal difference between the N cycle and P cycle in CLM-CNP is the presence of these inorganic P pools. Solution P is the most readily available $\mathrm{P}$ in soils that can be directly taken up by plants and microbes. Labile $\mathrm{P}$ is the soil $\mathrm{P}$ that is loosely adsorbed on soil particle surfaces and readily exchanges with soil solution P. Based on observations (Cole et al., 1977), it is assumed that solution $\mathrm{P}$ and labile $\mathrm{P}$ are in equilibrium for the time step we use $(30 \mathrm{~min})$. Labile $\mathrm{P}$ can be further adsorbed onto soil mineral particles and become secondary mineral $\mathrm{P}$. Secondary mineral $\mathrm{P}$ can be dissolved and enter labile P. At the same time, secondary mineral $\mathrm{P}$ is slowly transformed into occluded $\mathrm{P}$, which is considered unavailable for plant uptake. $P$ enters terrestrial ecosystems by the weathering of parent material, mainly apatite. Dust input of $\mathrm{P}$ is also important in some regions (Okin et al., 2004; Chadwick et al., 1999). $P$ is lost from the system due to leaching, depending on the size of the solution P pool and water runoff. A full list of model variables for the $\mathrm{P}$ submodel is provided in Table 1 .

The representation of soil inorganic P pools in CLM-CNP is different from that of existing CNP modeling approaches (Wang et al., 2007, 2009; Goll et al., 2012). The five inorganic P pools we implement in the model are based on the measurements using the Hedley fractionation method (Hedley and Stewart, 1982; Tiessen and Moir, 1993; Yang and Post, 2011). The Heldey fractionation method has been 
well established as a comprehensive way to measure soil $\mathrm{P}$ (Smeck, 1985; Johnson et al., 2003; Cross and Schlesinger, 1995). The newly expanded global Hedley P database (Yang and Post, 2011) and the increasing number of soil P measurements using the Hedley fractionation method will be helpful for model parameterization and evaluation. Our recently published global maps of various forms of $\mathrm{P}$ (using the same terminology) will provide a reasonable initialization for future applications of CLM-CNP on the global scale (Yang et al., 2013). Additionally, solution $P$ dynamics is explicitly modeled in CLM-CNP for the following reasons: (1) we assume plants can only take up P in soil solution; (2) we use a $30 \mathrm{~min}$ the time step, the relationship between solution $\mathrm{P}$ and labile $\mathrm{P}$ can be described using the Langmuir equation; and (3) the explicit modeling of solution $\mathrm{P}$ is needed to model the $P$ leaching flux.

\subsubsection{Representation of $P$ limitation}

The model employs a supply-demand approach to resolve $\mathrm{P}$ limitation, in which supply is controlled by soil solution $\mathrm{P}$ and demand is the sum of plant and microbial $\mathrm{P}$ demand. At each time step, if the supply of $\mathrm{P}$ is insufficient to meet the demand, plant growth and microbial immobilization is downregulated.

Plant $\mathrm{P}$ demand $\left(F_{\text {plant_demand }}^{\mathrm{P}}\right)$ is the amount of $\mathrm{P}$ needed for the allocation of new growth to various tissue types based on specified $\mathrm{C}: \mathrm{P}$ ratios for each tissue type and allometric parameters that relate allocation between various tissues (see Supplement A). Plant P demand from soil is the difference between total plant $\mathrm{P}$ demand and the $\mathrm{P}$ flux from the retranslocated $\mathrm{P}$ pool. $\mathrm{P}$ demand for microbial immobilization is the sum of all potential $\mathrm{P}$ immobilization fluxes during litter and soil organic matter decomposition $\left(F_{\text {immob_demand }}^{\mathrm{P}}\right.$, see Supplement B). Total $\mathrm{P}$ demand from soil $\left(F_{\text {total demand }}^{\mathrm{P}}\right)$ is the sum of plant $\mathrm{P}$ demand from soil and microbial $\mathrm{P}$ demand. If the soil solution P pool is large enough to meet with plant and microbial $\mathrm{P}$ demand, $\mathrm{P}$ is not a limiting nutrient for either plant growth or decomposition. In that case, $f_{\text {immob }}^{\mathrm{P}}$ and $f_{\text {plant }}^{\mathrm{P}}$ are both set to 1 . On the other hand, if there is not enough $\mathrm{P}$ in the soil solution to satisfy the total $\mathrm{P}$ demand, the $\mathrm{P}$ limiting factors are defined as

$f_{\text {immob }}^{\mathrm{P}}=f_{\text {plant }}^{\mathrm{P}}=\frac{\mathrm{P}_{\text {sol }}}{F_{\text {total_demand }}^{\mathrm{P}}}$.

\subsubsection{N limitation vs. P limitation}

Compared with CLM-CN, the most important modification for the C cycle in CLM-CNP is that both plant growth and decomposition can be limited by either $\mathrm{N}$ or $\mathrm{P}$, depending on which one is more limiting. We assume that the most limiting nutrient will determine the overall nutrient limitation following the Liebig law.

$f_{\text {plant }}=\min \left(f_{\text {plant }}^{\mathrm{N}}, f_{\text {plant }}^{\mathrm{P}}\right)$ $f_{\text {plant }}$ is the overall nutrient limiting factor on plant growth, $f_{\text {plant }}^{\mathrm{P}}$ is the fraction of the plant $\mathrm{P}$ demand that can be met given the $\mathrm{P}$ supply and competition with microbial $\mathrm{P}$ immobilization (see Sect. 2.1.1), $f_{\text {plant }}^{\mathrm{N}}$ is fraction of the plant $\mathrm{P}$ demand that can be met given the $\mathrm{N}$ supply and competition with microbial $\mathrm{N}$ immobilization.

$f_{\mathrm{immob}}=\min \left(f_{\mathrm{immob}}^{\mathrm{N}}, f_{\mathrm{immob}}^{\mathrm{P}}\right)$

$f_{\text {immob }}$ is the overall nutrient limiting factor during decomposition, $f_{\text {immob }}^{\mathrm{P}}$ is the fraction of potential immobilization demand that can be met given the supply of $\mathrm{P}$ (see Sect. 2.1.1), and $f_{\mathrm{immob}}^{\mathrm{N}}$ is the fraction of potential immobilization demand that can be met given the supply of $\mathrm{N}$.

\subsubsection{P dynamics in plants and soil organic matter}

Plant $\mathrm{P}$ uptake is determined by downregulating plant $\mathrm{P}$ demand from soils with $f_{\text {plant }}$. Total flux of $\mathrm{P}$ for allocation to new growth is the sum of plant $\mathrm{P}$ uptake from soils and $\mathrm{P}$ flux from the retranslocated $\mathrm{P}$ pool. We model the dynamics of $\mathrm{P}$ in plant tissue pools following the same methodology as for $\mathrm{N}$. P allocation flux is calculated based on the stoichiometric relationship of $\mathrm{C}, \mathrm{N}$ and $\mathrm{P}$ in plant tissues. $\mathrm{C}: \mathrm{P}$ ratios for plant tissues are prescribed and kept constant.

Litter and soil organic $\mathrm{P}$ dynamics are modeled as follows:

$$
\begin{aligned}
& \frac{\mathrm{d} P_{11}}{\mathrm{~d} t}=\sum_{i} F_{\mathrm{L}, i \rightarrow l 1}-F_{\mathrm{M}, 11 \rightarrow \mathrm{s} 1}, \\
& \frac{\mathrm{d} P_{12}}{\mathrm{~d} t}=\sum_{i} F_{\mathrm{L}, i \rightarrow 12}-F_{\mathrm{M}, 12 \rightarrow \mathrm{s} 2}, \\
& \frac{\mathrm{d} P_{13}}{\mathrm{~d} t}=\sum_{i} F_{\mathrm{L}, i \rightarrow l 3}-F_{\mathrm{M}, l 3 \rightarrow \mathrm{s} 3},
\end{aligned}
$$

$\frac{\mathrm{d} P_{\mathrm{s} 1}}{\mathrm{~d} t}=F_{\mathrm{M}, 11 \rightarrow s 1}-F_{\mathrm{M}, \mathrm{s} 1 \rightarrow \mathrm{s} 2}-F_{\mathrm{s} 1, \text { biochem }}$,

$\frac{\mathrm{d} P_{\mathrm{s} 2}}{\mathrm{~d} t}=F_{\mathrm{M}, l 2 \rightarrow \mathrm{s} 2}+F_{\mathrm{M}, \mathrm{s} 1 \rightarrow \mathrm{s} 2}-F_{\mathrm{M}, \mathrm{s} 2 \rightarrow \mathrm{s} 3}-F_{\mathrm{s} 2, \text { biochem }}$,

$\frac{\mathrm{d} P_{\mathrm{s} 3}}{\mathrm{~d} t}=F_{\mathrm{M}, l 3 \rightarrow \mathrm{s} 3}+F_{\mathrm{M}, \mathrm{s} 2 \rightarrow \mathrm{s} 3}-F_{\mathrm{M}, \mathrm{s} 3 \rightarrow \mathrm{s} 4}-F_{\mathrm{s} 3, \text { biochem }}$,

$\frac{\mathrm{d} P_{\mathrm{s} 4}}{\mathrm{~d} t}=F_{\mathrm{M}, \mathrm{s} 3 \rightarrow \mathrm{s} 4}-F_{\mathrm{M}, \mathrm{s} 4}-F_{\mathrm{s} 4, \text { biochem }}$,

where the subscript $i$ (in Eqs. 1, 2 and 3) represent plant tissue pools (leaf, fine root, live wood, dead wood, live coarse 
Table 1. List of variables and their definitions.

\begin{tabular}{|c|c|c|}
\hline Symbol & Description & Unit \\
\hline$P_{i}$ & Amount of $\mathrm{P}$ in $i$ th pool (for vegetation, litter and soil organic pools) & $\mathrm{gPm}^{-2}$ \\
\hline$P_{\text {sol }}$ & Amount of $\mathrm{P}$ in soil solution & $\mathrm{gPm}^{-2}$ \\
\hline$P_{\text {lab }}$ & Amount of labile inorganic $\mathrm{P}$ in soil & $\mathrm{gPm}^{-2}$ \\
\hline$P_{\mathrm{sec}}$ & Amount of secondary mineral inorganic $\mathrm{P}$ in soil & $\mathrm{gPm}^{-2}$ \\
\hline$P_{\mathrm{ocl}}$ & Amount of occluded P in soil & $\mathrm{gPm}^{-2}$ \\
\hline$P_{\text {pri }}$ & Amount of parent material $\mathrm{P}$ in soil & $\mathrm{gPm}^{-2}$ \\
\hline$F_{\mathrm{M}, i \rightarrow j}$ & Flux of $\mathrm{P}$ from $i$ th pool to $j$ th pool & $\mathrm{gPm}^{-2} \mathrm{~s}^{-1}$ \\
\hline$F_{i, \text { biochem }}$ & Biochemical mineralization rate of the ith soil pool & $\mathrm{gPm}^{-2} \mathrm{~s}^{-1}$ \\
\hline$F_{\mathrm{W}}$ & Flux of $\mathrm{P}$ from parent material weathering to soil & $\mathrm{gPm}^{-2} \mathrm{~s}^{-1}$ \\
\hline$F_{\mathrm{D}}$ & Flux of $\mathrm{P}$ from atmospheric deposition to soil & $\mathrm{gPm}^{-2} \mathrm{~s}^{-1}$ \\
\hline$F_{\mathrm{M}}$ & Sum of all biological mineralization P fluxes & $\mathrm{gPm}^{-2} \mathrm{~s}^{-1}$ \\
\hline$F_{\text {biochem }}$ & Sum of all biochemical P mineralization fluxes & $\mathrm{gPm}^{-2} \mathrm{~s}^{-1}$ \\
\hline$F_{1}$ & Flux of $\mathrm{P}$ from leaching & $\mathrm{gPm}^{-2} \mathrm{~s}^{-1}$ \\
\hline$F_{\text {uptake }}$ & Flux of P by plant uptake & $\mathrm{gPm}^{-2} \mathrm{~s}^{-1}$ \\
\hline$S_{\max }$ & Maximum amount of labile $\mathrm{P}$ in soil & $\mathrm{gPm}^{-2}$ \\
\hline$K_{\mathrm{S}}$ & The empirical constant representing the tendency of soil solution $\mathrm{P}$ for adsorption & \\
\hline$r_{\mathrm{ad}}$ & Rate constant for conversion of labile $\mathrm{P}$ to secondary mineral $\mathrm{P}$ & $\mathrm{s}^{-1}$ \\
\hline$r_{\mathrm{des}}$ & Rate constant for desorption of secondary mineral $\mathrm{P}$ & $\mathrm{s}^{-1}$ \\
\hline$r_{\mathrm{ocl}}$ & Rate constant for conversion of secondary P minerals to occluded P & $\mathrm{s}^{-1}$ \\
\hline$r_{\text {wea }}$ & Rate constant for weathering of parent material $\mathrm{P}$ & $\mathrm{s}^{-1}$ \\
\hline$f_{\mathrm{immob}}^{\mathrm{N}}$ & Fraction of potential immobilization demand that can be met given the supply of $\mathrm{N}$ & \\
\hline$f_{\text {immob }}^{\mathrm{pm}}$ & Fraction of potential immobilization demand that can be met given the supply of $\mathrm{P}$ & \\
\hline$f_{\text {immob }}$ & Limitation factor on decomposition based on the most limiting nutrient ( $\mathrm{N}$ or $\mathrm{P})$ & \\
\hline$f_{\text {plant }}^{\mathrm{N}}$ & Fraction of the plant $\mathrm{N}$ demand that can be met given the $\mathrm{N}$ supply & \\
\hline & and competition with microbial $\mathrm{P}$ immobilization & \\
\hline$f_{\text {plant }}^{\mathrm{P}}$ & Fraction of the plant $\mathrm{P}$ demand that can be met given the $\mathrm{P}$ supply & \\
\hline & and competition with microbial $P$ immobilization & \\
\hline $\begin{array}{l}J_{\text {plant }} \\
k_{\mathrm{bc}}\end{array}$ & Specific biochemical mineralization rate & $\mathrm{s}^{-1}$ \\
\hline$\tau_{\mathrm{bc}}$ & Scaling factor for biochemical mineralization & \\
\hline
\end{tabular}

root, dead coarse root); $\sum_{i} F_{\mathrm{L}, i \rightarrow l 1} \sum_{i} F_{\mathrm{L}, i \rightarrow l 2}$ and $\sum_{i} F_{\mathrm{L}, i \rightarrow l 3}$ are the fluxes of $\mathrm{P}$ from the plant tissue pools to the three litter pools; $F_{\mathrm{M}, 11 \rightarrow \mathrm{s} 1}, F_{\mathrm{M}, 12 \rightarrow \mathrm{s} 2}, F_{\mathrm{M}, 13 \rightarrow \mathrm{s} 3}, F_{\mathrm{M}, \mathrm{s} 1 \rightarrow \mathrm{s} 2}, F_{\mathrm{M}, \mathrm{s} 2 \rightarrow \mathrm{s} 3}$, $F_{\mathrm{M}, \mathrm{s} 3 \rightarrow \mathrm{s} 4}$, and $F_{\mathrm{M}, \mathrm{s} 4}$ are the fluxes of $\mathrm{P}$ between litter pools and soil organic pools (11-13, s1-s4) during decomposition (see Appendix B). The decomposition fluxes can be limited by the availability of mineral $\mathrm{N}$ and $\mathrm{P}$, defined by the limitation factor of the more limiting nutrient ( $\mathrm{N}$ or $\mathrm{P}$; Eq. 3 ) in the CLM-CNP model.

$F_{\mathrm{s} 1 \text {, biochem }}, F_{\mathrm{s} 2 \text {, biochem }}, F_{\mathrm{s} 3 \text {, biochem }}, F_{\mathrm{s} 4 \text {, biochem }}$ are the $\mathrm{P}$ fluxes from four soil organic matter pools due to biochemical mineralization (see below).

\section{Biochemical mineralization}

$\mathrm{P}$ in soil organic matter bound by phosphate ester bonds can be independently mineralized by phosphatase enzymes (McGill and Cole, 1981). Phosphatase enzymes can be produced by both plants and soil microbes in response to $\mathrm{P}$ limitation (Stewart and Tiessen, 1987). Fertilization studies showed that phosphatase activity often decreases after P fertilizer application (McGroddy et al., 2004b; Allison and Vitousek, 2005). Since phosphatase enzymes are N-rich proteins with $15-20 \% \mathrm{~N}$ on a mass basis (Wang et al., 2007), $\mathrm{N}$ availability can affect the phosphatase mediated biochemical mineralization. The biochemical mineralization rate of $\mathrm{P}$ is calculated as

$F_{i, \text { biochem }}=P_{i} k_{\mathrm{bc}} f_{\mathrm{immob}}^{\mathrm{N}}\left(1.0-e^{\tau_{\mathrm{bc}}\left(1-f_{\mathrm{immob}}^{\mathrm{P}}\right)}\right)$,

where $P_{i}$ is the $i$ th soil $\mathrm{P}$ pool, $f_{\text {immob }}^{\mathrm{N}}$ and $f_{\text {immob }}^{\mathrm{P}}$ are $\mathrm{N}$ and $\mathrm{P}$ limiting factors during decomposition, $k_{\mathrm{bc}}$ is the specific biochemical mineralization rate. $\tau_{\mathrm{bc}}$ is the scaling factor for biochemical mineralization. This formulation allows us to account for the controls on biochemical mineralization from the perspectives of phosphorus availability, $\mathrm{N}$ availability, and the size of organic $P$.

\subsubsection{Inorganic P dynamics}

It is assumed the solution $\mathrm{P}$ rapidly equilibrates with the labile P. Cole et al. (1977) showed that the solution pool is replenished from the labile pool at a potential rate of 250 times per day. For the $30 \mathrm{~min}$ time step used here, we assume the solution pool and labile pool are in equilibrium. The relationship between solution $\mathrm{P}\left(P_{\text {sol }}\right)$ and labile $\mathrm{P}\left(P_{\text {lab }}\right)$ is described by the modified Langmuir equation (Barrow, 1978):

$P_{\mathrm{lab}}=\frac{S_{\mathrm{max}} P_{\mathrm{sol}}}{K_{\mathrm{s}}+P_{\mathrm{sol}}}$, 
where $S_{\max }$ is the maximum amount of labile $\mathrm{P}$ in the soil, and $\mathrm{Ks}$ is the empirical constant representing the tendency of soil solution $\mathrm{P}$ for adsorption, with smaller values corresponding to a higher tendency for adsorption.

The differential form is

$\frac{\mathrm{d} P_{\mathrm{lab}}}{\mathrm{d} t}=\frac{S_{\mathrm{max}} P_{\mathrm{sol}}}{\left(K_{\mathrm{s}}+P_{\mathrm{sol}}\right)^{2}} \frac{\mathrm{d} P_{\mathrm{sol}}}{\mathrm{d} t}$.

Since we assume that solution $\mathrm{P}$ and labile $\mathrm{P}$ are in equilibrium at a $30 \mathrm{~min}$ timescale, the changes in solution $\mathrm{P}$ and labile $\mathrm{P}$ together can be modeled as

$$
\begin{aligned}
& \frac{\mathrm{d}\left(P_{\text {sol }}+P_{\text {lab }}\right)}{\mathrm{d} t}=F_{\mathrm{w}}+F_{\mathrm{D}}+F_{\mathrm{M}}+F_{\text {biochem }}-F_{1} \\
& -r_{\mathrm{ad}} P_{\text {lab }}-F_{\text {uptake }},
\end{aligned}
$$

where $F_{\mathrm{w}}$ is the $\mathrm{P}$ flux from weathering of parent material $\mathrm{P}$, $F_{D}$ is the $\mathrm{P}$ flux from atmospheric deposition, $F_{\mathrm{M}}$ is the net $\mathrm{P}$ flux from biological mineralization, $F_{\text {biochem }}$ is the $\mathrm{P}$ flux associated with biochemical mineralization, $F_{1}$ is the leaching loss of $\mathrm{P}, r_{\mathrm{ad}}$ is the rate constant for conversion of labile $\mathrm{P}$ to secondary mineral $\mathrm{P}$, and $F_{\text {uptake }}$ is the $\mathrm{P}$ taken up by plants.

From Eqs. (13) and (14), solution P dynamics can be modeled as

$$
\begin{aligned}
& \frac{\mathrm{d} P_{\text {sol }}}{\mathrm{d} t}=\frac{1}{1+\frac{S_{\max } K_{\mathrm{s}}}{\left(P_{\text {sol }}+K_{\mathrm{s}}\right)^{2}}}\left(F_{\mathrm{w}}+F_{\mathrm{D}}+F_{\mathrm{M}}+F_{\text {biochem }}-F_{1}\right. \\
& \left.-r_{\mathrm{ad}} P_{\text {lab }}-F_{\text {uptake }}\right) .
\end{aligned}
$$

Labile P dynamics can be modeled as

$$
\begin{aligned}
& \frac{\mathrm{d} P_{\text {lab }}}{\mathrm{d} t}=\frac{S_{\mathrm{max}} K_{\mathrm{S}}}{\left(\left(P_{\mathrm{sol}}+K_{\mathrm{S}}\right)^{2}+S_{\mathrm{max}} K_{\mathrm{S}}\right)}\left(F_{\mathrm{w}}+F_{\mathrm{D}}+F_{\mathrm{M}}\right. \\
& \left.+F_{\text {biochem }}-F_{1}-r_{\mathrm{ad}} P_{\text {lab }}-F_{\text {uptake }}\right) .
\end{aligned}
$$

Secondary P dynamics are modeled as

$$
\frac{\mathrm{d} P_{\mathrm{sec}}}{\mathrm{d} t}=r_{\mathrm{ad}} P_{\mathrm{lab}}-r_{\mathrm{des}} P_{\mathrm{sec}}-r_{\mathrm{ocl}} P_{\mathrm{sec}},
$$

where $r_{\mathrm{ad}}$ is the rate constant for conversion of labile P to secondary mineral $\mathrm{P}, r_{\text {des }}$ is the rate constant for desorption of secondary mineral $\mathrm{P}, P_{\mathrm{sec}}$ is the size of secondary mineral $\mathrm{P}$ pool, $r_{\text {ocl }}$ is the rate constant for conversion of secondary $\mathrm{P}$ minerals to occluded $P$.

Occluded $\mathrm{P}$ dynamics are modeled as

$\frac{\mathrm{d} P_{\mathrm{ocl}}}{\mathrm{d} t}=r_{\mathrm{ocl}} P_{\mathrm{sec}}$.

P flux from weathering is modeled as

$$
\frac{\mathrm{d} P_{\mathrm{pri}}}{\mathrm{d} t}=r_{\mathrm{wea}} P_{\mathrm{pri}},
$$

where $r_{\text {wea }}$ is the specific weathering rate of primary mineral $\mathrm{P}$ (parent material), and $P_{\mathrm{pri}}$ is the amount of $\mathrm{P}$ in primary mineral form.

\subsection{Model spin-up}

We first run the model through accelerated decomposition (AD) spin-up and exit spin-up without P limitation. This is to initialize $\mathrm{P}$ pools in vegetation and soil organic pools using the stoichiometric relationship between $\mathrm{C}, \mathrm{N}$, and P. We skip accelerated decomposition spin-up for the $\mathrm{P}$ cycle, as $\mathrm{P}$ cycle involves various forms of inorganic $\mathrm{P}$ and the their transformations are controlled by geochemical processes, which are independent of decomposition. In the second step, we initialize the soil inorganic $\mathrm{P}$ pools using the site observations. Lastly we run the normal spin-up with P limitation turned on, allowing $\mathrm{C}, \mathrm{N}$, and $\mathrm{P}$ cycles to equilibrate.

\subsection{Site information}

\subsubsection{Hawaii chronosequence sites}

We examined the performance of CLM-CNP at sites along a soil-formation chronosequence in Hawaii (Vitousek, 2004). The sites along the chronosequence have similar climate condition with mean annual temperatures of $16^{\circ} \mathrm{C}$ and about $2500 \mathrm{~mm}$ of average annual precipitation. The sites were all developed from basaltic tephra or lava flows, having similar parent material. All the sites are dominated by the tree Metrosideros polymorpha. The soil ages of the sites range from 300 years to 4 million years. The differences in soil age lead to differences in weathering stage, soil biogeochemistry, soil mineralogy and nutrient limitation among sites. Observations provide information about plant production, vegetation and soil organic matter $\mathrm{C}, \mathrm{N}$, and $\mathrm{P}$, different forms of $\mathrm{P}$ in soils, $\mathrm{N}$ and $\mathrm{P}$ losses, $\mathrm{N}$ and $\mathrm{P}$ mineralization and soil respiration at each site along the chronosequence. The long-term field fertilization experiment along the chronosequence also provides an ideal opportunity for understanding and modeling nutrient limitation in soils at different weathering stages. The two sites we choose for model evaluation include one very young site (300 years), which is N limited, and the oldest site (4 million years old), which is P limited. The soils at the $\mathrm{N}$-limited site are classified as entisols, while the soils of the P-limited site are defined as oxisols.

\subsubsection{Amazon sites}

The five sites used in this study are part of the intensively surveyed plots within the RAINFOR network (Amazon Forest Inventory Network; http://www.rainfor.org). The sites were selected to encompass a range of soil $\mathrm{P}$ availability, with soil available $P$ generally decreasing from west to east across Amazonia. The forests at these sites are primary old-growth rainforest (Aragão et al., 2009). A summary of site name, location, basic climate data, and soil available $\mathrm{P}$ for the sites can be found in Table 2. For a more detailed view of the site information see Aragão (2009). 
Table 2. Site code, locations and climatic characteristics of the five Amazonian sites used in this study.

\begin{tabular}{llrrrrr}
\hline Site code & Name & \multicolumn{2}{c}{ Location } & \multicolumn{2}{c}{ Climate } & Available \\
\cline { 3 - 6 } & & lat. & long. & $\begin{array}{r}\text { Rainfall } \\
\left(\mathrm{mm} \mathrm{a}^{-1}\right)\end{array}$ & $\begin{array}{r}\text { Temp } \\
\left({ }^{\circ} \mathrm{C}\right)\end{array}$ & $\begin{array}{r}\text { soil P } \\
\left(\mathrm{mg} \mathrm{kg}^{-1}\right)\end{array}$ \\
\hline TAM-06 & $\begin{array}{l}\text { Tamboapata } \\
\text { RAINFOR plot }\end{array}$ & -12.9 & -69.8 & 2417 & 25.2 & 33.06 \\
AGP-01 & $\begin{array}{l}\text { Agua pudre } \\
\text { plot E }\end{array}$ & -3.72 & -70.3 & 2723 & 25.5 & 25.36 \\
BR-Sa3 & $\begin{array}{l}\text { Tapajós flux } \\
\text { tower site }\end{array}$ & -2.5 & -55.0 & 1968 & 26.1 & 15.45 \\
BR-Cax & $\begin{array}{l}\text { Caxiuanã flux } \\
\text { tower site }\end{array}$ & -1.72 & -51.5 & 2314 & 26.9 & 12.31 \\
MAN-05 & Manaus & -2.5 & -60.0 & 2272 & 27.1 & 7.28 \\
\hline
\end{tabular}

Table 3. Parameters of the P model used in this study.

\begin{tabular}{|c|c|c|c|}
\hline & \multicolumn{2}{|c|}{ Hawaii sites $^{\mathrm{a}}$} & \multirow[t]{2}{*}{ Amazon sites } \\
\hline & $\begin{array}{l}\text { N-limited site } \\
\text { (Thurston) }\end{array}$ & $\begin{array}{l}\text { P-limited site } \\
\text { (Kokee) }\end{array}$ & \\
\hline Leaf $\mathrm{C}: \mathrm{P}$ & 800 & 700 & $600^{\mathrm{d}}$ \\
\hline Leaf litter $\mathrm{C}: \mathrm{P}$ & 1600 & 1260 & $1200^{\mathrm{e}}$ \\
\hline Fine $\operatorname{root} \mathrm{C}: \mathrm{P}$ & 850 & 1750 & $1000^{\mathrm{e}}$ \\
\hline Live wood $C: P$ & 4500 & 5500 & $3000^{e}$ \\
\hline Dead wood C:P & 4500 & 5500 & $3000^{\mathrm{e}}$ \\
\hline SOM1 C :P & 400 & 200 & $500^{\mathrm{b}}$ \\
\hline SOM2 C:P & 400 & 200 & $500^{\mathrm{b}}$ \\
\hline SOM3 C : P & 400 & 200 & $500^{\mathrm{b}}$ \\
\hline SOM4 C : P & 400 & 200 & $500^{\mathrm{b}}$ \\
\hline$S_{\max }{ }^{\mathrm{b}}$ & 10 & 10 & 10 \\
\hline$K_{\mathrm{S}}^{\mathrm{b}}$ & 0.005 & 0.00035 & 0.0009 \\
\hline$r_{\mathrm{ad}} \mathrm{b}, \mathrm{c}$ & 0.001 & 0.005 & 0.004 \\
\hline$r_{\mathrm{des}} \mathrm{b}, \mathrm{c}$ & 0.00022 & 0.00022 & 0.00022 \\
\hline$r_{\mathrm{Ocl}} \mathrm{b}, \mathrm{c}$ & $1.0 \mathrm{e}-6$ & $1.0 \mathrm{e}-6$ & $1.0 \mathrm{e}-6$ \\
\hline$r_{\text {wea }} \mathrm{b}, \mathrm{c}$ & 0.001 & 0.0001 & 0.0001 \\
\hline$k_{\mathrm{bc}}^{\mathrm{b}, \mathrm{c}}$ & 0. & 0.0005 & 0.0005 \\
\hline$\tau_{\mathrm{bc}} \mathrm{f}$ & -5 & -5 & -5 \\
\hline
\end{tabular}

${ }^{\mathrm{a}} \mathrm{C}: \mathrm{P}$ ratio is from Vitousek (2004), ${ }^{\mathrm{b}}$ calibrated value, ${ }^{\mathrm{c}}$ the unit here is in $\mathrm{month}^{-1}$, ${ }^{d}$ based on Aragão et al.(2009), ${ }^{\mathrm{e}}$ based on Wang et al. (2010) and Herbert (2003), ${ }^{\mathrm{f}}$ based on Goll et al. (2012)

\subsection{Model setup and calibration}

\subsubsection{Model setup for Hawaii chronosequence sites}

We use observed weather data from a nearby airport (http:// www.ncdc.noaa.gov/oa/climate/ghcn-daily/), adjusted for elevation using a standard lapse rate. We parameterized the model using site measurements. We used the measured $P$ pool sizes from each site to constrain the $\mathrm{P}$ dynamic parameters (Table 3 ). The only $\mathrm{C}$ cycle parameter that was adjusted is the specific decomposition rate for the slowest soil organic matter pool, as the original CLM4-CN model significantly underestimates the slow soil organic carbon pools. After the model was calibrated for the sites, model runs were set up to simulate the effects of adding only $\mathrm{N}$, only $\mathrm{P}$, and $\mathrm{N}$ and $\mathrm{P}$ together at these two sites. A total of $10 \mathrm{~g} \mathrm{~N} \mathrm{~m}^{-2} \mathrm{a}^{-1}$ and $10 \mathrm{~g}$ $\mathrm{P} \mathrm{m}^{-2} \mathrm{a}^{-1}$ were added in the model simulations, the same amount as applied in the field fertilization experiment (Harrington et al., 2001; Vitousek, 2004).

\subsubsection{Model calibration at Amazon sites}

Our primary calibration site is a mature tropical evergreen forest at the TAM-06 site (Table 2). We first used the uncertainty quantification (UQ) package (Sargsyan et al., 2013) to narrow down the range of some important parameters needed in the model. Next, based on the measurements at this calibration site (NPP, vegetation C and P contents and soil P pools), five parameters controlling available $P$ and the transformations of soil inorganic $\mathrm{P}$ were optimized through a more traditional "trial and error" iterative calibration procedure (Table 3, see Amazon site column). To assess the general applicability of the parameterized model to Amazon tropical forests, we applied the calibrated parameter set to four other sites (Table 2) that have a gradient of available P (Fig. 4a). The use of a single parameter set ensures that simulated variations in NPP are due entirely to differences in the climate condition and soil properties, not to differences in parameters.

\section{Model applications}

\subsection{Simulating shifts in nutrient limitation along the Hawaii chronosequence}

Figure 2a shows that at the N-limited site, CLM-CN simulated NPP is consistent with observations, as well as leaf $\mathrm{C}$, root $\mathrm{C}$, and litter C. CLM-CN overestimated C in wood and coarse root and underestimated soil organic C. CLMCNP produced the same results as CLM-CN as $\mathrm{P}$ is in adequate supply at this young N-limited site. As shown in Fig. 2b, introduction of P limitation greatly improved model 

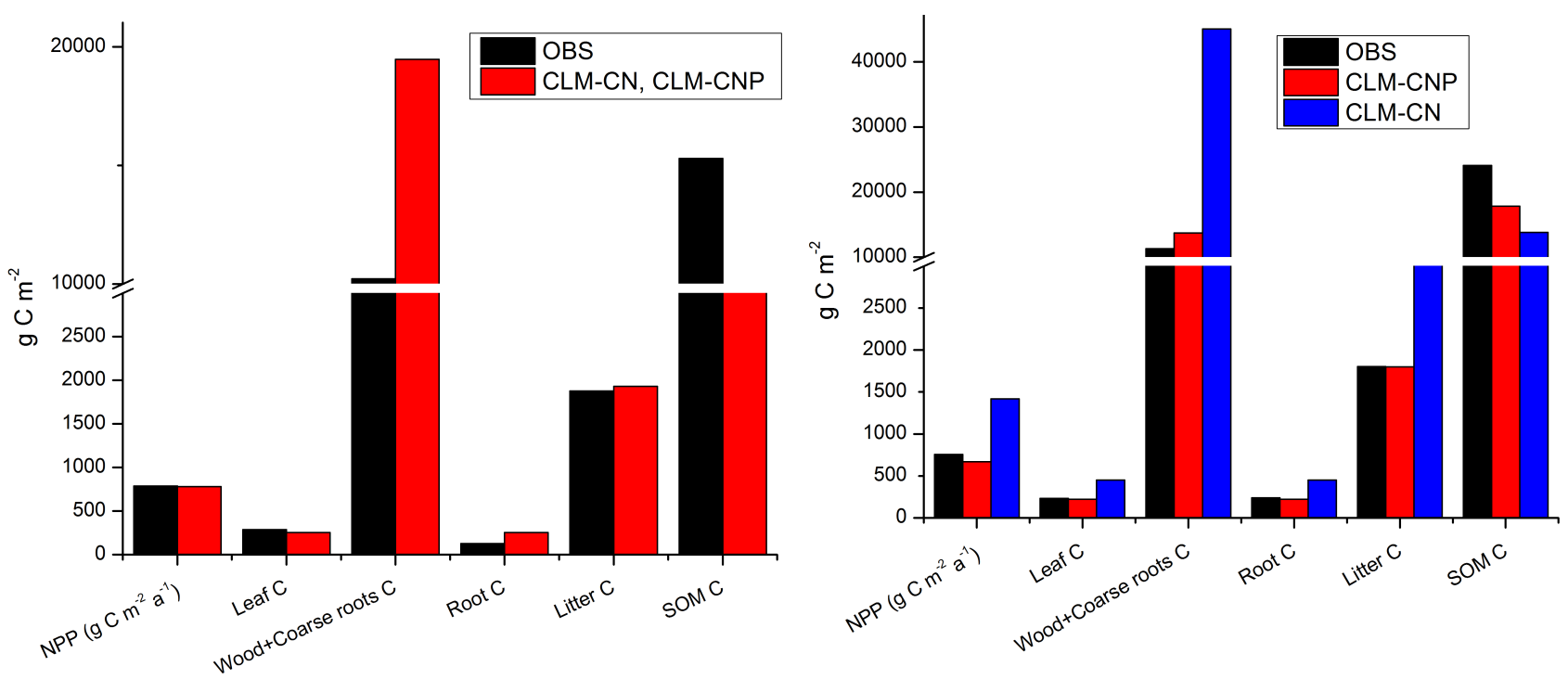

Fig. 2. Comparison between model simulations (CLM-CNP and CLM-CN) and the observations at the (a) N-limited site, and (b) P-limited site in the Hawaii chronosequence.

performance at the P-limited site. CLM4-CN overestimated NPP at this site, most likely because of lack of consideration of strong P limitation. CLM-CNP was able to simulate NPP more reasonably and as a result the simulated $\mathrm{C}$ in leaf, wood plus coarse root, and root litter were all greatly improved. The higher SOM (soil organic matter) C in CLM-CNP is due to the adjustment of the specific decomposition rate of the slowest SOM pool.

To test the influence of leaf $\mathrm{C}: \mathrm{P}$ on $\mathrm{P}$ limitation, we have run the simulation at the P-limited site using the leaf $\mathrm{C}: \mathrm{P}$ ratio of the N-limited site (Table 3 ) and the simulated NPP is only slightly higher (about $3 \%$ ). Considering that NPP was reduced by about half in the CLM-CNP simulation, compared to the $\mathrm{CN}$ simulation (Fig. 2b), we believe P limitation at this site is mainly caused by soil $\mathrm{P}$ availability rather than the larger $\mathrm{P}$ demand induced by the lower leaf $\mathrm{C}: \mathrm{P}$ ratio.

For the fertilization simulations, model results are generally consistent with the observed data from the fertilization experiments at both $\mathrm{N}$-limited and P-limited sites (Fig. 3). Adding $\mathrm{N}$ to a $\mathrm{N}$-limited site results in substantial increase in plant production, while adding $\mathrm{P}$ has no impact on production. However, the model underestimated the increase in plant production associated with the addition of $\mathrm{N}$ and $\mathrm{P}$ together at the $\mathrm{N}$-limited site, probably due to the overestimate of $\mathrm{P}$ availability. As for the $\mathrm{P}$-limited site, adding $\mathrm{N}$ showed no impact on production while adding phosphorus greatly increased plant production. However, the model-simulated stimulation of plant production from $\mathrm{P}$ fertilizer application is much lower than that from the experiments, because the model underestimates $\mathrm{N}$ availability when $\mathrm{P}$ is added (results not shown here). This could be because the model currently is not capturing the positive effect of $\mathrm{P}$ addition on $\mathrm{N}$ fixation. Parton et al. (2004) simulated the fertilization experiments using the CENTURY model and their model results also underestimated $\mathrm{N}$ availability and stimulated plant production when $P$ was added. They suggested that nitrogen input had to be increased by $1-2 \mathrm{~g} \mathrm{~N} \mathrm{~m}^{-2} \mathrm{a}^{-1}$ for CENTURY to correctly simulate the observed response to $P$ fertilizer application. In fact, the observed fertilizer response data suggested that nitrogen uptake had to be increased by at least $1 \mathrm{~g} \mathrm{~N} \mathrm{~m}^{-2} \mathrm{a}^{-1}$ with the addition of P. The discrepancy between model simulations and observations highlighted the importance of incorporating the effect of $\mathrm{P}$ availability on $\mathrm{N}$ fixation.

One limitation for the simulations along the Hawaii chronosequence is that we prescribed the soil $\mathrm{P}$ pools using site measurements rather than running the model from parent material to simulate soil and ecosystem development. A simulation over the time period of 4 million of years is infeasible for CLM as it requires unrealistic computation time. Realistic driver data are also not available for this long time period.

\subsection{Simulating the control of soil P status on NPP at five RAINFOR sites}

Generally the introduction of P limitation (CLM-CNP versus CLM-CN) improved the modeled NPP at the Amazon forest sites, reducing the high bias in NPP simulated by the CN model across all five sites (Fig. 4b). MAPE (mean absolute percent error)(Kothamasu et al., 2004) is $7 \%$ for CLM-CNP and $15 \%$ for CLM-CN. There is a tendency of greater NPP towards the sites with greater $\mathrm{P}$ availability in model simulations, consistent with the observed pattern in Amazonian forests (Aragão et al., 2009). The notable exception is the Tapajos tropical evergreen forest BR-Sa3 site. The CN model simulates a larger NPP at this site than at the two adjacent 

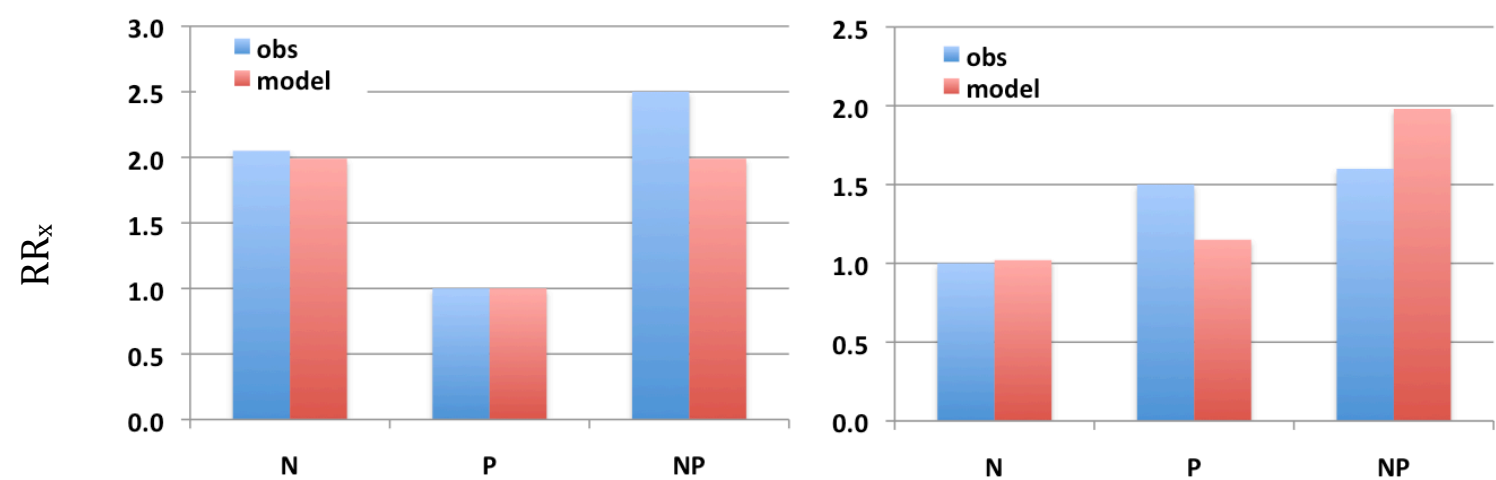

Fig. 3. Comparison of the model-simulated fertilization effect with the observations at (a) N-limited sites and (b) P-limited sites along the Hawaii chronosequence. $\mathrm{RR}_{\mathrm{X}}$ (response ratio) represents the measured or modeled plant production in the fertilizer treatment divided by its value in the unfertilized condition.
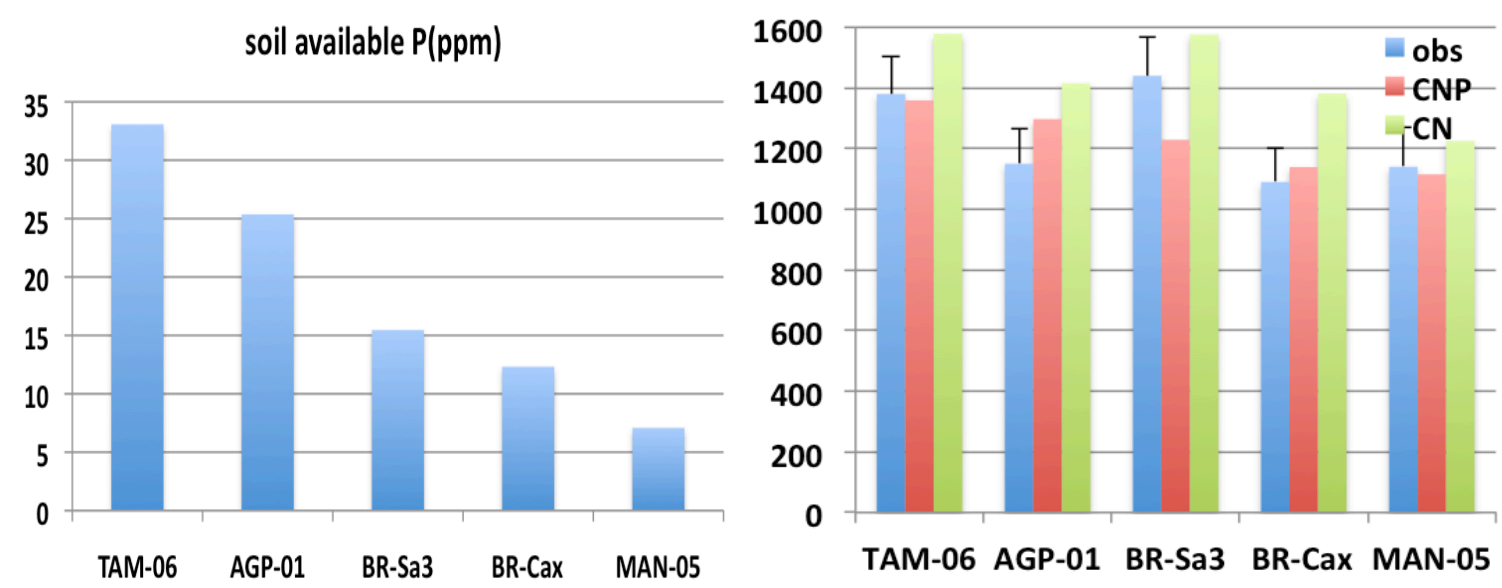

Fig. 4. (a) The amount of soil available $\mathrm{P}\left(\mathrm{mg} \mathrm{kg}^{-1}\right)$ for the five Amazonian sites (a). Comparison of model-simulated NPP $\left(\mathrm{g} \mathrm{m}^{-2} \mathrm{a}^{-1}\right)$ with the observations (with standard error bars) at the five Amazonian sites. Observations are from Aragão (2009).

sites, mainly because of higher incident solar radiation in the driver data. The introduction of $\mathrm{P}$ limitation at this site leads to worse rather than better model performance, suggesting that the simulated, strong P limitation at this site is probably not realistic. Previous studies suggested that this site had undergone large-scale mortality events before the measurement was taken (Pyle et al., 2008; Malhi et al., 2009). Disturbances can greatly affect the nutrient dynamics and limitation in terrestrial ecosystems, for example, shifting limitation away from $\mathrm{P}$ and toward $\mathrm{N}$ limitation in P-limited tropical forests (Herbert et al., 2003). The suggested mechanism for this disturbance-dependent shift in nutrient limitation is that $\mathrm{N}$ is more mobile relative to $\mathrm{P}$ in ecosystems, and with disturbances $\mathrm{N}$ losses through leaching and gas emissions are larger than losses of P. Davidson et al. (2004) showed that nitrogen is more limiting than phosphorus in a tropical secondary forest growing on a highly weathered P-poor oxisol. They suggested that repeated fire and other losses of $\mathrm{N}$ might render tree growth $\mathrm{N}$ limited in these young Amazonian forests.
Uncertainty in the measurements may also contribute to the discrepancy between model-simulated NPP and observations. At the AGP-01 site, the introduction of P limitation improved the model-simulated NPP compared with CN model, but modeled NPP is still much higher than observed. This discrepancy arises very likely because of the underestimation of canopy productivity in the observations. Canopy productivity is based on the measurement of litterfall, which can decompose or be consumed by herbivores before reaching the ground. The rates of decomposition and herbivore consumption may be highest at the wetter sites, especially at the AGP-01 site with higher rainfall and lack of dry season compared to the other four sites (Aragão et al., 2009).

\subsection{P limitation vs. $\mathbf{N}$ limitation in tropical forests}

As shown in Fig. 5, across the five Amazon sites, CLM-CNP shows strong P limitation, although seasonality of P limitation varies among sites. $\mathrm{N}$ limitation acts as secondary limitation in CLM-CNP at these sites, dominated by P limitation most of the time. However periodically there is a shift from $P$ 

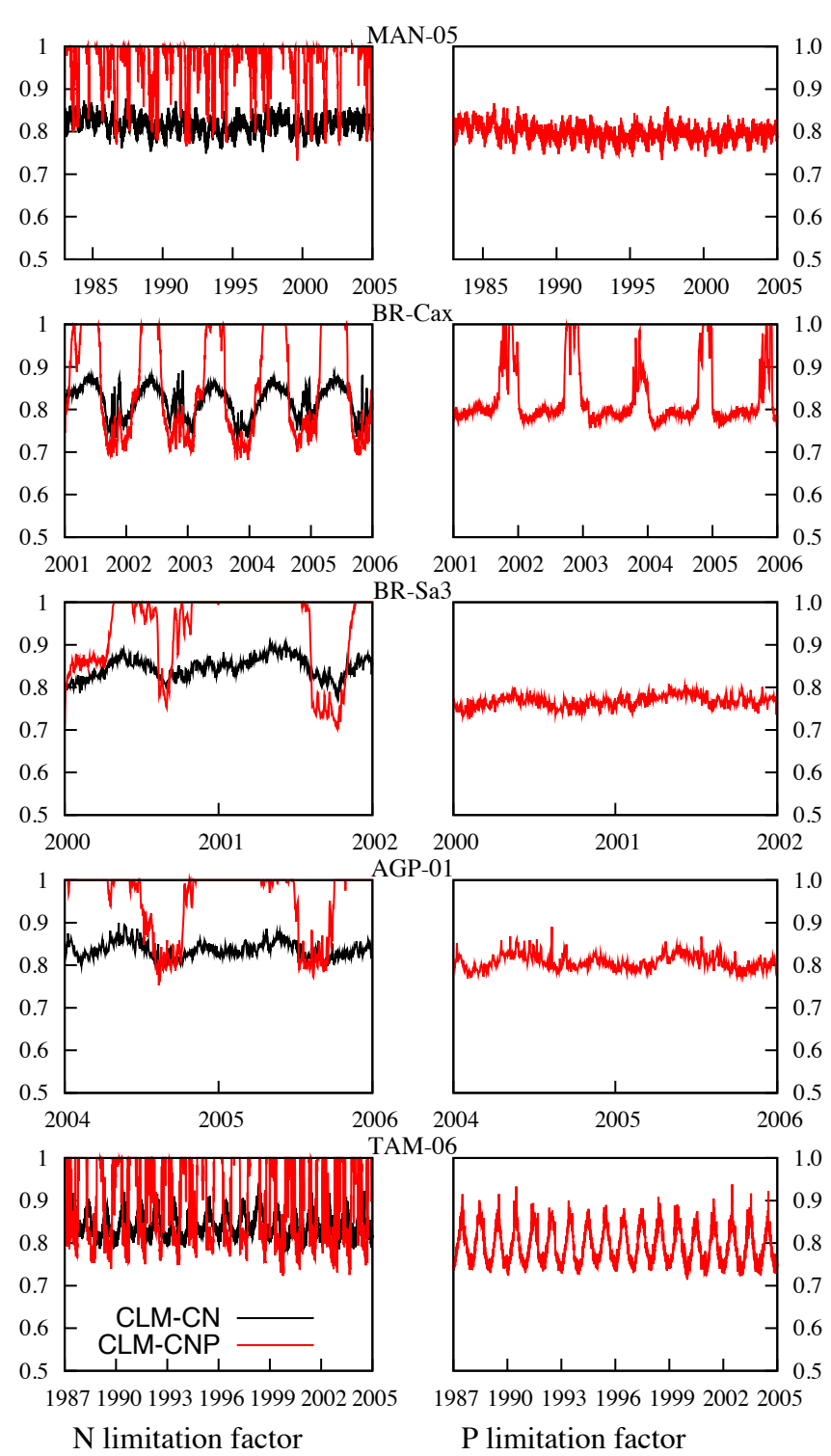

Fig. 5. The extent of nutrient limitation ( $\mathrm{N}$ and $\mathrm{P}$ for CLM-CNP, $\mathrm{N}$ for CLM4-CN) for the five Amazonian sites.

limitation to $\mathrm{N}$ limitation, suggesting the presence of $\mathrm{N}-\mathrm{P}$ colimitation at these tropical forest sites. The CLM-CN model shows strong $\mathrm{N}$ limitation at the five sites, and the extent of $\mathrm{N}$ limitation is comparable to $\mathrm{P}$ limitation in CLM-CNP. The present-day similarity between the extent of $\mathrm{N}$ limitation in CLM-CN and P limitation in CLM-CNP, however, does not imply that $\mathrm{N}$ limitation is a good surrogate for $\mathrm{P}$ limitation in the future. As discussed previously, the $\mathrm{N}$ cycle and $\mathrm{P}$ cycle have different characteristics and their response to changes in atmospheric $\mathrm{CO}_{2}$ and climate will also be quite different. Therefore, introduction of $\mathrm{P}$ limitation and $\mathrm{C}-\mathrm{N}-\mathrm{P}$ interactions explicitly in CLM help improve our understanding and representation of $\mathrm{C}$-nutrient interactions in tropical forests, which will be critical for better prediction of nutrient con- straint on future carbon uptake in P-limited tropical forest ecosystems.

\subsection{How might $\mathrm{C}-\mathrm{P}$ interactions affect ecosystem responses to elevated $\left[\mathrm{CO}_{2}\right]$}

$\mathrm{CO}_{2}$ fertilization of vegetation growth has been suggested as an important negative feedback operating on atmospheric $\mathrm{CO}_{2}$ concentration $\left(\left[\mathrm{CO}_{2}\right]\right)$. However, both the magnitude and the future projection of this important mechanism depend to large extent on $P$ availability in tropical forest ecosystems growing on highly weathered P-poor soils. Figure 6 shows the feedback loops between the $\mathrm{C}$ cycle and $\mathrm{P}$ cycle that could affect the tropical forest's responses to elevated $\left[\mathrm{CO}_{2}\right]$. Increased plant growth under an elevated $\left[\mathrm{CO}_{2}\right]$ condition could lead to the increase of $\mathrm{P}$ demand in order to sustain the increasing productivity stimulated by the elevated $\left[\mathrm{CO}_{2}\right]$ and the sequestration of $\mathrm{P}$ into increased amounts of long-lived plant biomass and soil organic matter (assuming relatively constrained stoichiometry relationship between $\mathrm{C}$ and $\mathrm{P}$ ). These mechanisms could further reduce soil $\mathrm{P}$ availability, leading to progressive $\mathrm{P}$ limitation (PPL) in tropical forests, if there were no increase of available $P$ or decrease of $\mathrm{P}$ loss. The concept of PPL is analogous to PNL (progressive $\mathrm{N}$ limitation) (Luo et al., 2004). However, there are several key differences between the $\mathrm{P}$ cycle and $\mathrm{N}$ cycle: (1) the total amount of $\mathrm{P}$ in the systems can be considered quasi-constant on the timescale of decades or even centuries; (2) the amount of $\mathrm{P}$ available for plant utilization is only a small proportion of total $\mathrm{P}$, and is determined not only by biological but also geochemical processes such as adsorption and desorption; and (3) the presence of phosphatase enzymes that help release inorganic $\mathrm{P}$ from soil organic matter independent of carbon and nitrogen. It becomes apparent that we need to better understand the relevant feedback effects associated with the $\mathrm{P}$ cycle in order to assess the tropical forest's responses to $\left[\mathrm{CO}_{2}\right]$.

One of the most important processes controlling $\mathrm{P}$ availability is biochemical mineralization of organic $\mathrm{P}$ through phosphatase activity. Under P deficiency, plants can increase the production of phosphatase enzymes, and increase the mineralization of organic $\mathrm{P}$ into available inorganic P. Under elevated $\left[\mathrm{CO}_{2}\right]$, both fine root growth and mycorrhizal associations are stimulated (Iversen et al., 2008; Treseder, 2004), both of which are capable of producing phosphatase enzymes and facilitating the conversion of organic $\mathrm{P}$ to inorganic P. Therefore, this enzymatic feedback pathway could potentially be important for $\mathrm{P}$ availability and the extent of $\mathrm{P}$ limitation under elevated $\left[\mathrm{CO}_{2}\right]$. Another important process controlling $\mathrm{P}$ availability is through the competition for sorption sites between phosphate ions and other compounds such as organic acid and SOM. Increased SOM and production of organic acid could result in increased $\mathrm{P}$ desorption, due to SOM coating of iron- and aluminum-oxide minerals and occupation of sorption sites by organic acid, which would 


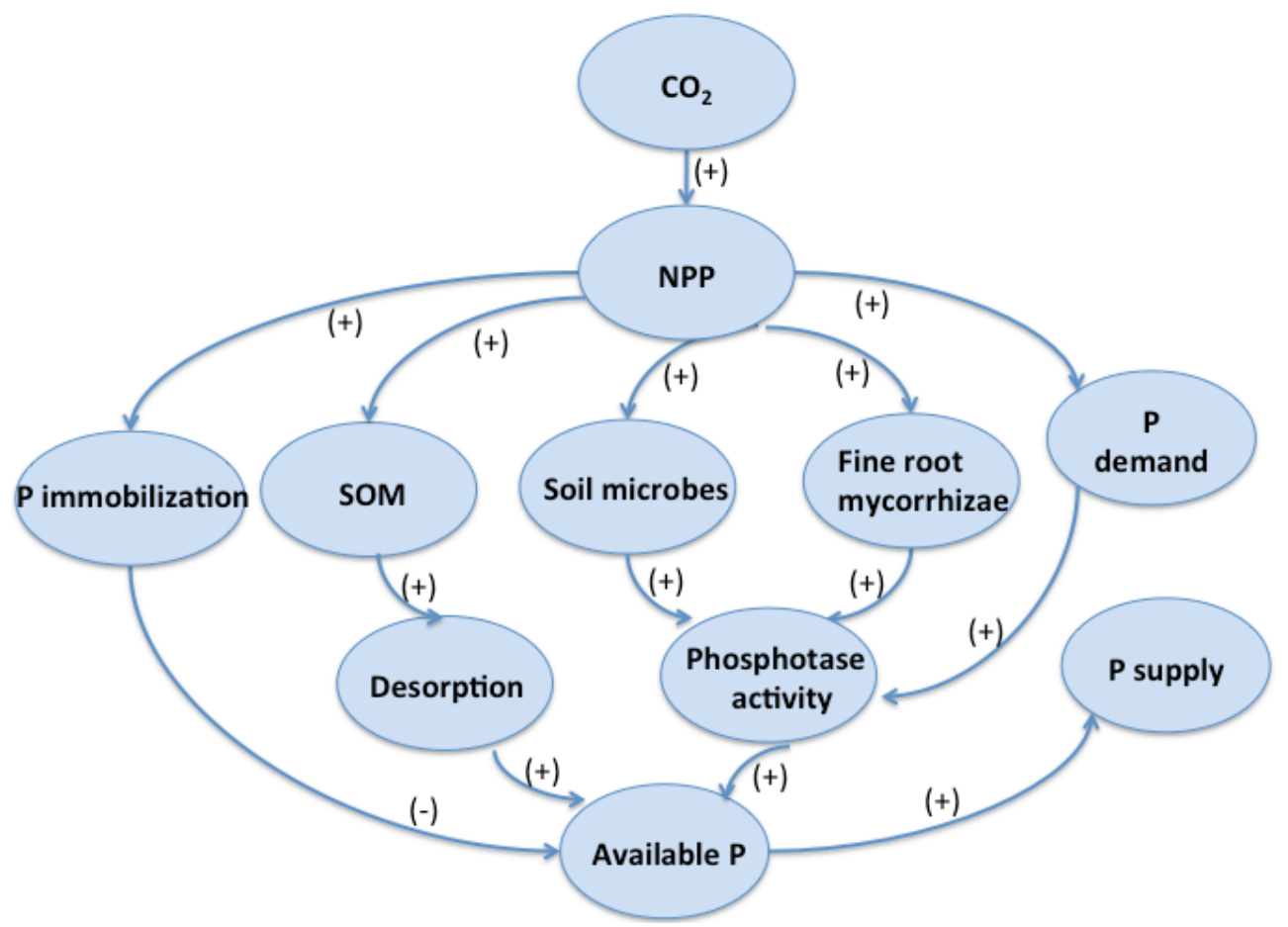

Fig. 6. Feedback loops between $\mathrm{C}$ and $\mathrm{P}$ cycles that affect tropical ecosystem responses to elevated $\left[\mathrm{CO}_{2}\right]$.

lead to increased availability of $\mathrm{P}$. This geochemical pathway would also be crucial for the tropical forest's responses to elevated $\left[\mathrm{CO}_{2}\right]$.

To explore the importance of these aforementioned processes that affect $\mathrm{P}$ availability to the ecosystem responses to increasing $\left[\mathrm{CO}_{2}\right]$, we conducted three simulations at the TAM-06 site with doubled $\left[\mathrm{CO}_{2}\right]$. Specifically, we first ran the model using historical atmospheric $\left[\mathrm{CO}_{2}\right]$ until 2009, and starting from 2010 we increased atmospheric $\mathrm{CO}_{2}$ concentration to $800 \mathrm{ppm}$ (roughly doubled compared with $390 \mathrm{ppm}$ in 2009) and continued to run three model simulations for 40 more years: control (desorption rate and specific biochemical mineralization rate kept unchanged), enhanced biochemical mineralization (biochemical mineralization rate doubled), and enhanced desorption (desorption rate doubled).

With the doubling of $\left[\mathrm{CO}_{2}\right], \mathrm{NPP}$ is instantly stimulated by about $15 \%$ but the stimulation effect diminished in a few years due to the decreased availability of $\mathrm{P}$ in the control simulation (Fig. 7a). It is of considerable importance whether biochemical mineralization of organic $\mathrm{P}$ is enhanced, or whether desorption of phosphate from soil mineral surfaces are increased under elevated $\left[\mathrm{CO}_{2}\right]$ conditions. As shown in Fig. 7a, as long as biochemical mineralization or desorption is stimulated under elevated $\left[\mathrm{CO}_{2}\right]$, the ecosystem responses to increasing $\left[\mathrm{CO}_{2}\right]$ can be sustained. The sustainability of the responses occurs at different costs in terms of soil P pools for these simulations. The soil's organic P pool is decreasing continually when biochemical mineralization is increased (Fig. 7c), while the soil's secondary mineral P pool keeps decreasing when desorption is enhanced (Fig. 7d). The soil's organic $\mathrm{P}$ and secondary mineral $\mathrm{P}$ pools thus play a key role in replenishing the $\mathrm{P}$ supply under elevated $\left[\mathrm{CO}_{2}\right]$. Since the total amount of $\mathrm{P}$ in terrestrial ecosystems is practically constant over the timescale of decades to centuries, the ecosystem response to $\left[\mathrm{CO}_{2}\right]$ will ultimately be determined by soil P.

These simulations indicate that ecosystem responses to $\left[\mathrm{CO}_{2}\right]$ strongly depend on a range of processes that affect $\mathrm{P}$ availability. Better understanding and incorporation of these processes in models are needed in order to improve our predictive capability on the interactions between ecosystems and climate.

\section{Conclusions and discussions}

Realizing the importance of $\mathrm{P}$ limitation in tropical forest ecosystems, we developed a $\mathrm{P}$ cycling component for the CLM4-CN model to improve the model's representation of $\mathrm{C}$-nutrient interactions in tropical regions. The $\mathrm{P}$ model incorporates all major processes governing $\mathrm{P}$ cycling and the interactions with the $\mathrm{C}$ cycle and $\mathrm{N}$ cycle. Model simulations at sites along the Hawaii chronosequence show that the introduction of $\mathrm{P}$ limitation improved model performance at the $\mathrm{P}$ limited site. The comparison of simulated to observed plant production responses to fertilizer application shows that the model results are generally consistent with the observed data. However, the model tends to underestimate the positive effect 

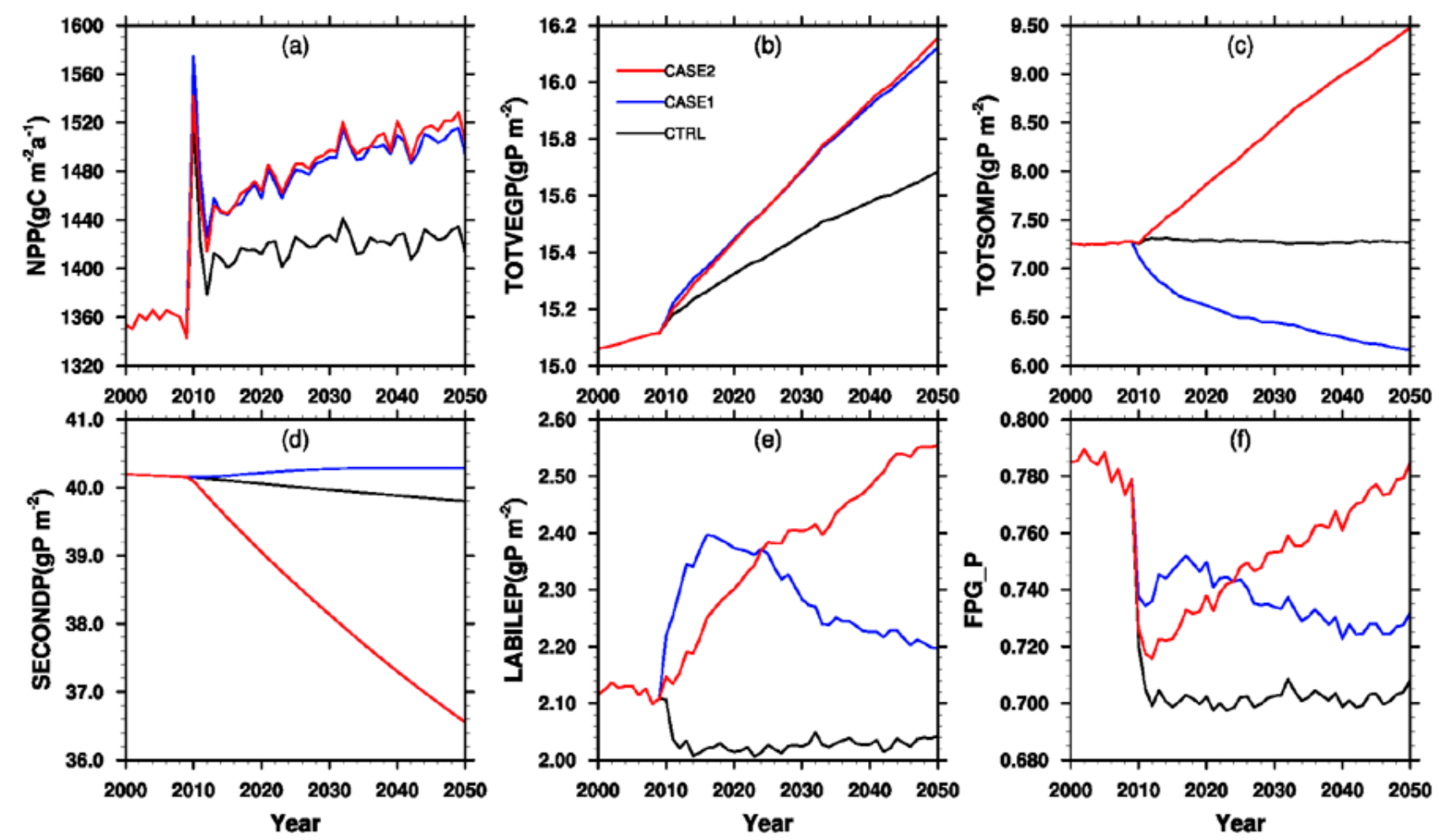

Fig. 7. Simulated time course of (a) net primary production, $(\mathbf{b})$ vegetation $\mathrm{P},(\mathbf{c})$ soil organic $\mathrm{P}$, $(\mathbf{d})$ secondary mineral $\mathrm{P}\left(P_{\mathrm{sec}}\right)$, (e) labile $\mathrm{P}\left(P_{\text {lab }}\right)$, and (f) the degree of $\mathrm{P}$ limitation $\left(f_{\text {plant }}^{\mathrm{P}}\right)$ for three simulation cases. Control: default parameters (desorption rate and specific biochemical mineralization rate kept unchanged). Case 1: enhanced biochemical mineralization (biochemical mineralization rate doubled). Case 2: enhanced desorption (desorption rate doubled).

of adding $\mathrm{P}$ fertilizer at the $\mathrm{P}$-limited site, due to the lack of consideration of the positive effect of $\mathrm{P}$ addition on $\mathrm{N}$ fixation. The model simulations of the Amazonian forest sites show that CLM-CNP is capable of capturing the overall trend in NPP along the P availability gradient. Site characteristics and land use history may help explain discrepancies between models results and observations.

Our model experiments under elevated the $\mathrm{CO}_{2}$ condition suggest that the tropical forest's responses to increasing $\left[\mathrm{CO}_{2}\right]$ will interact strongly with changes in the $\mathrm{P}$ cycle. We highlighted the importance of two pathways (geochemical and enzymatic) that can significantly affect $P$ availability and determine the extent of $\mathrm{P}$ limitation in tropical forests under elevated $\mathrm{CO}_{2}$. The enzymatic pathway (biochemical mineralization of organic P) can be enhanced with increased production of phosphatase enzymes, which is stimulated by the enhanced growth of fine root, mycorrhizal fungi and soil microbes under elevated $\mathrm{CO}_{2}$. The geochemical pathway (increased desorption of secondary $\mathrm{P}$ minerals), can also be enhanced when increased $\mathrm{SOM}$ under elevated $\mathrm{CO}_{2}$ occupies more of the sorption sites on soil minerals. These processes are poorly constrained by measurements currently available (Goll et al., 2012) and there are no available field measurements of how elevated $\left[\mathrm{CO}_{2}\right]$ affects these processes. Field experiments with elevated $\mathrm{CO}_{2}$ are therefore needed to help quantify these important feedbacks in order to move from conceptual to predictive modeling of C-P interactions. This will have important implications for the prediction of future carbon uptake and storage in tropical ecosystems and global climate change.

This study represents an important step forward in representing $\mathrm{C}$-nutrient interactions in earth system models. There are several limitations in our model. The first is that our model does not account for the effect of $\mathrm{P}$ availability on $\mathrm{N}$ fixation. Although both theoretical understanding and experimental data suggest that $\mathrm{N}$ fixation may be controlled by $\mathrm{P}$ availability (Cleveland et al., 1999; Houlton et al., 2008; Edwards et al., 2006), the mechanisms controlling $\mathrm{N}$ fixation remain elusive. The second uncertainty comes from our simplistic approach for modeling sorption and desorption. As shown in this study, sorption and desorption control the shift of $\mathrm{P}$ between unavailable forms and available forms and can determine the extent of $\mathrm{P}$ limitation. Sorption and desorption may be affected by soil $\mathrm{pH}$ and redox fluctuation, which are not represented in the current model due to limited data and quantitative process understanding. Further studies are needed to better understand and quantify the controls on sorption and desorption. Thirdly, our model does 
not yet consider the effects of land use change. Future studies with CLM-CNP will evaluate how changes in land cover and land use affect nutrient dynamics and $\mathrm{C}$ uptake in tropical forests. Additionally, a comprehensive sensitivity analysis would help us to improve our understanding of the model and quantify model uncertainties, which will be an important part of our future research.

\section{Supplementary material related to this article is available online at http://www.biogeosciences.net/11/ 1667/2014/bg-11-1667-2014-supplement.pdf.}

Acknowledgements. This research was sponsored by the US Department of Energy, Office of Science, Biological and Environmental Research (BER) programs and performed at Oak Ridge National Laboratory (ORNL). ORNL is managed by UT-Battelle, LLC, for the US Department of Energy under contract no. DEAC05-00OR22725. We would like to thank Kirsten Thonicke, Sönke Zaehle and one anonymous reviewer for their constructive comments and suggestions.

Edited by: K. Thonicke

\section{References}

Allison, S. D. and Vitousek, P. M.: Responses of extracellular enzymes to simple and complex nutrient inputs, Soil Biol. Biochem., 37, 937-944, 2005.

Aragão, L. E. O. C., Malhi, Y., Metcalfe, D. B., Silva-Espejo, J. E., Jiménez, E., Navarrete, D., Almeida, S., Costa, A. C. L., Salinas, N., Phillips, O. L., Anderson, L. O., Alvarez, E., Baker, T. R., Goncalvez, P. H., Huamán-Ovalle, J., Mamani-Solórzano, M., Meir, P., Monteagudo, A., Patiño, S., Peñuela, M. C., Prieto, A., Quesada, C. A., Rozas-Dávila, A., Rudas, A., Silva Jr., J. A., and Vásquez, R.: Above- and below-ground net primary productivity across ten Amazonian forests on contrasting soils, Biogeosciences, 6, 2759-2778, doi:10.5194/bg-6-2759-2009, 2009.

Arneth, A., Harrison, S. P., Zaehle, S., Tsigaridis, K., Menon, S., Bartlein, P. J., Feichter, J., Korhola, A., Kulmala, M., and O'donnell, D.: Terrestrial biogeochemical feedbacks in the climate system, Nature Geosci., 3, 525-532, 2010.

Barron, A. R., Wurzburger, N., Bellenger, J. P., Wright, S. J., Kraepiel, A. M., and Hedin, L. O.: Molybdenum limitation of asymbiotic nitrogen fixation in tropical forest soils, Nature Geosci., 2, 42-45, 2008.

Campbell, C. D. and Sage, R. F.: Interactions between the effects of atmospheric $\mathrm{CO}_{2}$ content and $\mathrm{P}$ nutrition on photosynthesis in white lupin (Lupinus albus L.), Plant, Cell Environ., 29, 844 853,2006

Chadwick, O., Derry, L., Vitousek, P., Huebert, B., and Hedin, L.: Changing sources of nutrients during four million years of ecosystem development, Nature, 397, 491-497, 1999.

Clark, D. A.: Detecting tropical forests' responses to global climatic and atmospheric change: current challenges and a way forward, Biotropica, 39, 4-19, 2007.
Cleveland, C. and Liptzin, D.: C:N : P stoichiometry in soil: is there a "Redfield ratio" for the microbial biomass?, Biogeochemistry, 85, 235-252, 2007.

Cleveland, C., Townsend, A., Schimel, D., Fisher, H., Howarth, R., Hedin, L., Perakis, S., Latty, E., Von Fischer, J., and Elseroad, A.: Global patterns of terrestrial biological nitrogen (N2) fixation in natural ecosystems, Global Biogeochem. Cy., 13, 623-645, 1999.

Cole, C. V., Innis, G. S., and Stewart, J.: Simulation of phosphorus cycling in semiarid grasslands, Ecology, 58, 2-15, 1977.

Crews, T. E., Farrington, H., and Vitousek, P. M.: Changes in asymbiotic, heterotrophic nitrogen fixation on leaf litter of Metrosideros polymorpha with long-term ecosystem development in Hawaii, Ecosystems, 3, 386-395, 2000.

Cross, A. and Schlesinger, W.: A literature review and evaluation of the. Hedley fractionation: Applications to the biogeochemical cycle of soil phosphorus in natural ecosystems, Geoderma, 64, 197-214, 1995.

Davidson, E. A., Reis de Carvalho, C. J., Vieira, I. C., Figueiredo, R. d. O., Moutinho, P., Yoko Ishida, F., Primo dos Santos, M. T., Benito Guerrero, J., Kalif, K., and Tuma Sabá, R.: Nitrogen and phosphorus limitation of biomass growth in a tropical secondary forest, Ecol. Appl., 14, 150-163, 2004.

Domingues, T. F., Meir, P., Feldpausch, T. R., Saiz, G., Veenendaal, E. M., Schrodt, F., Bird, M., Djagbletey, G., Hien, F., and Compaore, H.: Colimitation of photosynthetic capacity by nitrogen and phosphorus in West Africa woodlands, Plant, Cell Environ., 33, 959-980, 2010.

Edwards, E., McCaffery, S., and Evans, J.: Phosphorus availability and elevated $\mathrm{CO}_{2}$ affect biological nitrogen fixation and nutrient fluxes in a clover dominated sward, New Phytol., 169, 157-167, 2006.

Elser, J. J., Bracken, M. E. S., Cleland, E. E., Gruner, D. S., Harpole, W. S., Hillebrand, H., Ngai, J. T., Seabloom, E. W., Shurin, J. B., and Smith, J. E.: Global analysis of nitrogen and phosphorus limitation of primary producers in freshwater, marine and terrestrial ecosystems, Ecol. Lett., 10, 1135-1142, 2007.

Evans, J. R.: Photosynthesis and nitrogen relationships in leaves of C3 plants, Oecologia, 78, 9-19, 1989.

Foley, J. A., DeFries, R., Asner, G. P., Barford, C., Bonan, G., Carpenter, S. R., Chapin, F. S., Coe, M. T., Daily, G. C., and Gibbs, H. K.: Global consequences of land use, Science, 309, 570-574, 2005.

Friedlingstein, P., Cox, P., Betts, R., Bopp, L., Von Bloh, W., Brovkin, V., Cadule, P., Doney, S., Eby, M., and Fung, I.: Climate-carbon cycle feedback analysis: Results from the C4MIP model intercomparison, J. Climate, 19, 3337-3353, 2006.

Geiger, D. R. and Servaites, J. C.: Diurnal regulation of photosynthetic carbon metabolism in C3 plants, Ann. Rev. Plant Biol., 45, 235-256, 1994.

Goll, D. S., Brovkin, V., Parida, B. R., Reick, C. H., Kattge, J., Reich, P. B., van Bodegom, P. M., and Niinemets, Ü.: Nutrient limitation reduces land carbon uptake in simulations with a model of combined carbon, nitrogen and phosphorus cycling, Biogeosciences, 9, 3547-3569, doi:10.5194/bg-9-3547-2012, 2012.

Harrington, R. A., Fownes, J. H., and Vitousek, P. M.: Production and resource use efficiencies in $\mathrm{N}$-and $\mathrm{P}$-limited tropical forests: 
a comparison of responses to long-term fertilization, Ecosystems, 4, 646-657, 2001.

Hedley, M. and Stewart, J.: Method to measure microbial phosphate in soils, Soil Biol. Biochem., 14, 377-385, 1982.

Herbert, D. A., Williams, M., and Rastetter, E. B.: A model analysis of $\mathrm{N}$ and $\mathrm{P}$ limitation on carbon accumulation in Amazonian secondary forest after alternate land-use abandonment, Biogeochemistry, 65, 121-150, 2003.

Houlton, B. Z., Wang, Y.-P., Vitousek, P. M., and Field, C. B.: A unifying framework for dinitrogen fixation in the terrestrial biosphere, Nature, 454, 327-330, 2008.

Hungate, B. A., Stiling, P. D., Dijkstra, P., Johnson, D. W., Ketterer, M. E., Hymus, G. J., Hinkle, C. R., and Drake, B. G.: $\mathrm{CO}_{2}$ elicits long-term decline in nitrogen fixation, Science, 304, 1291-1291, 2004.

Iversen, C. M., Ledford, J., and Norby, R. J.: $\mathrm{CO}_{2}$ enrichment increases carbon and nitrogen input from fine roots in a deciduous forest, New Phytologist, 179, 837-847, 2008.

Jobbágy, E. G. and Jackson, R. B.: The vertical distribution of soil organic carbon and its relation to climate and vegetation, Ecol. Appl., 10, 423-436, 2000.

Johnson, A. H., Frizano, J., and Vann, D. R.: Biogeochemical implications of labile phosphorus in forest soils determined by the Hedley fractionation procedure, Oecologia, 135, 487-499, 2003.

Kothamasu, R., Shi, J., Huang, S. H., and Leep, H.: Comparison of selected model evaluation criteria for maintenance applications, Struct. Health Monit., 3, 213-224, 2004.

Luo, Y., Su, B., Currie, W. S., Dukes, J. S., Finzi, A., Hartwig, U., Hungate, B., Mc MURTRIE, R. E., Oren, R., and Parton, W. J.: Progressive nitrogen limitation of ecosystem responses to rising atmospheric carbon dioxide, Bioscience, 54, 731-739, 2004.

Malhi, Y., Aragao, L. E. O., Metcalfe, D. B., Paiva, R., Quesada, C. A., Almeida, S., Anderson, L., Brando, P., Chambers, J. Q., and COSTA, D.: Comprehensive assessment of carbon productivity, allocation and storage in three Amazonian forests, Glob. Change Biol., 15, 1255-1274, 2009.

Marklein, A. R. and Houlton, B. Z.: Nitrogen inputs accelerate phosphorus cycling rates across a wide variety of terrestrial ecosystems, New Phytol., 193, 696-704, 2012.

McGill, W. and Cole, C.: Comparative aspects of cycling of organic C, N, S and P through soil organic matter, Geoderma, 26, 267286, 1981.

McGroddy, M. E., Daufresne, T., and Hedin, L. O.: Scaling of C: N: $\mathrm{P}$ stoichiometry in forests worldwide: implications of terrestrial Redfield-type ratios, Ecology, 85, 2390-2401, 2004a.

McGroddy, M. E., Silver, W. L., and de Oliveira Jr., R. C.: The effect of phosphorus availability on decomposition dynamics in a seasonal lowland Amazonian forest, Ecosystems, 7, 172-179, 2004b.

Melillo, J. M., McGuire, A. D., Kicklighter, D. W., Moore, B., Vorosmarty, C. J., and Schloss, A. L.: Global climate change and terrestrial net primary production, Nature, 363, 234-240, 1993.

Mercado, L. M., Patiño, S., Domingues, T. F., Fyllas, N. M., Weedon, G. P., Sitch, S., Quesada, C. A., Phillips, O. L., Aragão, L. E., and Malhi, Y.: Variations in Amazon forest productivity correlated with foliar nutrients and modelled rates of photosynthetic carbon supply, Philosoph. Trans. Royal Soc. B, 366, 3316-3329, 2011.
Okin, G. S., Mahowald, N., Chadwick, O. A., and Artaxo, P.: Impact of desert dust on the biogeochemistry of phosphorus in terrestrial ecosystems, Global Biogeochem. Cy., 18, GB2005, doi:10.1029/2003GB002145, 2004.

Olander, L. P. and Vitousek, P. M.: Regulation of soil phosphatase and chitinase activityby $\mathrm{N}$ and $\mathrm{P}$ availability, Biogeochemistry, 49, 175-191, 2000.

Piao, S., Sitch, S., Ciais, P., Friedlingstein, P., Peylin, P., Wang, X., Ahlström, A., Anav, A., Canadell, J. G., and Cong, N.: Evaluation of terrestrial carbon cycle models for their response to climate variability and to $\mathrm{CO}_{2}$ trends, Glob. Change Biol., 19, 2117-2132, 2013.

Pyle, E. H., Santoni, G. W., Nascimento, H. E., Hutyra, L. R., Vieira, S., Curran, D. J., van Haren, J., Saleska, S. R., Chow, V., and Carmago, P. B.: Dynamics of carbon, biomass, and structure in two Amazonian forests, J. Geophys. Res. (2005-2012), 113, G00B08, doi:10.1029/2007JG000592, 2008.

Reed, S. C., Cleveland, C. C., and Townsend, A. R.: Relationships among phosphorus, molybdenum and free-living nitrogen fixation in tropical rain forests: results from observational and experimental analyses, Biogeochemistry, 1-13, 2013.

Reich, P. and Oleksyn, J.: Global patterns of plant leaf $\mathrm{N}$ and $\mathrm{P}$ in relation to temperature and latitude, Proc. Natl. Acad. Sci. USA, 101, 11001, doi:10.1073/pnas.0403588101, 2004.

Reich, P. B., Oleksyn, J., and Wright, I. J.: Leaf phosphorus influences the photosynthesis Äinitrogen relation: a cross-biome analysis of 314 species, Oecologia, 160, 207-212, 2009.

Sanchez, P. A.: Properties and Management of Soils in the Tropics, Soil Science, Wiley, 1976.

Smeck, N.: Phosphorus dynamics in soils and landscapes, Geoderma, 36, 185-199, 1985.

Stewart, J. and Tiessen, H.: Dynamics of soil organic phosphorus, Biogeochemistry, 4, 41-60, 1987.

Thornton, P., Doney, S., Lindsay, K., Moore, J., Mahowald, N., Randerson, J., Fung, I., Lamarque, J., Feddema, J., and Lee, Y.: Carbon-nitrogen interactions regulate climate-carbon cycle feedbacks: results from an atmosphere-ocean general circulation model, Biogeosciences, 6, 2099-2120, doi:10.5194/bg-6-20992009, 2009.

Thornton, P. E., Lamarque, J.-F., Rosenbloom, N. A., and Mahowald, N. M.: Influence of carbon-nitrogen cycle coupling on land model response to $\mathrm{CO}_{2}$ fertilization and climate variability, Global Biogeochem. Cy., 21, GB4018, doi:10.1029/2006gb002868, 2007.

Tiessen, H. and Moir, J. O.: Characterization of available P by sequential extraction, in: Soil sampling and methods of analysis, 2 ed., edited by: Carter, M., and GREGORICH, E., CRC Press, Taylor \& Francis Group, Boca Raton, FL, 75-86, 1993.

Treseder, K. K.: A meta-analysis of mycorrhizal responses to nitrogen, phosphorus, and atmospheric $\mathrm{CO}_{2}$ in field studies, New Phytol., 164, 347-355, 2004.

Treseder, K. K. and Vitousek, P. M.: Effects of soil nutrient availability on investment in acquisition of $\mathrm{N}$ and $\mathrm{P}$ in Hawaiian rain forests, Ecology, 82, 946-954, 2001.

Vitousek, P.: Nutrient cycling and limitation: Hawai'i as a model system, Princeton University, Princeton, 2004.

Walker, T. and Syers, J.: The fate of phosphorus during pedogenesis, Geoderma, 15, 1-19, 1976. 
Wang, Y. P., Houlton, B. Z., and Field, C. B.: A model of biogeochemical cycles of carbon, nitrogen, and phosphorus including symbiotic nitrogen fixation and phosphatase production, Global Biogeochem. Cy., 21, GB1018, doi:10.1029/2006gb002797, 2007.

Wright, S. J., Yavitt, J. B., Wurzburger, N., Turner, B. L., Tanner, E. V., Sayer, E. J., Santiago, L. S., Kaspari, M., Hedin, L. O., and Harms, K. E.: Potassium, phosphorus, or nitrogen limit root allocation, tree growth, or litter production in a lowland tropical forest, Ecology, 92, 1616-1625, 2011.

Yang, X. and Post, W. M.: Phosphorus transformations as a function of pedogenesis: A synthesis of soil phosphorus data using Hedley fractionation method, Biogeosciences, 8, 2907-2916, doi:10.5194/bg-8-2907-2011, 2011.
Yang, X., Post, W. M., Thornton, P. E., and Jain, A.: The distribution of soil phosphorus for global biogeochemical modeling, Biogeosciences, 10, 2525-2537, doi:10.5194/bg-10-2525-2013, 2013.

Zaehle, S. and Dalmonech, D.: Carbon-nitrogen interactions on land at global scales: current understanding in modelling climate biosphere feedbacks, Curr. Opinion Environ. Sustainabil., 3, 311-320, 2011.

Zaehle, S., Friend, A., Friedlingstein, P., Dentener, F., Peylin, P., and Schulz, M.: Carbon and nitrogen cycle dynamics in the O-CN land surface model: 2 . Role of the nitrogen cycle in the historical terrestrial carbon balance, Global Biogeochem. Cy., 24, GB1006, doi:10.1029/2009GB003522, 2010. 